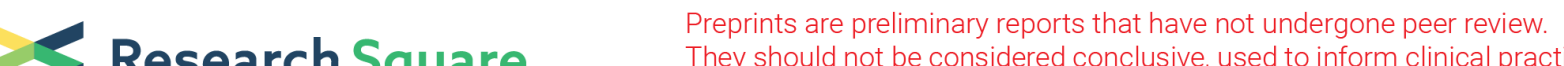 $\begin{array}{ll}\text { Research Square } & \text { They should not be considered conclusive, used to inform clinical practice, } \\ \text { or referenced by the media as validated information. }\end{array}$
}

\section{Prognostic Implication of Admission HbA1c for All- cause Mortality in Ischemic Heart Failure Among a Chinese Population: A Prospective Cohort Study}

\section{Weida Qiu}

Southern Medical University https://orcid.org/0000-0003-2206-8439

\section{Sicheng Chen}

Shantou University Medical College

\section{Anping Cai}

Guangdong Provincial Peoplel's Hospital: Guangdong Provincial People's Hospital

\section{Xiaoju Xiao}

Southern Medical University

\section{Zhiping Gao}

Guangdong Provincial Peoplel's Hospital: Guangdong Provincial People's Hospital

\section{Jijin Lin}

Guangdong Provincial Peoplel's Hospital: Guangdong Provincial People's Hospital

\section{Liwen Li ( $\nabla$ gdghllw@163.com )}

Guangdong Cardiovascular Institute

\section{Original investigation}

Keywords: Ischemic heart failure, HbA1c, All-cause mortality, sex, age

Posted Date: July 26th, 2021

DOl: https://doi.org/10.21203/rs.3.rs-728195/v1

License: (c) (1) This work is licensed under a Creative Commons Attribution 4.0 International License. Read Full License 


\section{Abstract}

Background: The impact of glycosylated hemoglobin A1c (HbA1c) on heart failure (HF) and ischemic heart disease (IHD) differs among studies, and IHD is a preponderant cause in HF. We investigated the link between admission $\mathrm{HbA} 1 \mathrm{c}$ and all-cause mortality in a Chinese population with ischemic heart failure (IHF).

Methods: Eligible patients with IHF at the Department of Cardiology, Guangdong Provincial People's Hospital from December 2015 to June 2019 were enrolled to investigate the association between admission $\mathrm{HbA} 1 \mathrm{c}$ and all-cause mortality of IHF with Kaplan-Meier survival analysis and Cox regression analysis.

Results: Of 1413 participants, the median age was $63.2 \pm 10.9$ years, $85 \%$ were men and median admission $\mathrm{HbA} 1 \mathrm{c}$ level was $6.82 \%$. All-cause mortality was higher in $\mathrm{HbA} 1 \mathrm{c}>7 \%$ group compared with $\mathrm{HbA1c} \leq 7 \%$ group (hazard ratio (HR): 1.328, 95\% confidence interval $(\mathrm{Cl}): 1.016-1.735, \mathrm{p}=0.037$ ), and sensitivity analysis appeared the consistent result. The association between $\mathrm{HbA} 1 \mathrm{c}$ and all-cause mortality was also statistically significant in the male and younger cohorts.

Conclusions: Elevated admission $\mathrm{HbA} 1 \mathrm{c}$ level $(>7 \%)$ is an independent risk factor for all-cause mortality of IHF in the general population, and there is also a consistent trend among male and younger individuals. Further explorations are required to elucidate whether glycemic management plays a crucial role in the progression of IHF within female and elderly population.

\section{Background}

As a global epidemic, heart failure (HF) confers a rapidly escalating prevalence with aging, as well as high mortality and ominous prognosis despite humble improvement in survival over the past decades [1, 2]. Ischemic heart disease (IHD) is the most prevailing risk factor of HF in Europe and North America [1]. It's projected that 700 million and 548.4 million individuals will develop diabetes and impaired glucose tolerance (IGT) worldwide by 2045, with $50.1 \%$ being undiagnosed diabetes in 2019 [3]. Type 2 diabetes mellitus (T2DM) is enormously frequent (30-40\%) in HF subjects and associated with worsening in hospitalization and readmission for HF, together with mortality, where coronary artery disease (CAD) is a major contributor to concomitant HF and T2DM [4]. Available data suggest that diabetes mellitus (DM) and IHD interact to hasten the progression of HF [5], and IHD adds further to unfavorable prognosis among HF patients with T2DM [6].

Glycosylated hemoglobin $\mathrm{A} 1 \mathrm{c}(\mathrm{HbA} 1 \mathrm{c})$ is the primary metric for assessing glycemic management and has been applied to date in clinical trials to determine the profit of glucose control [7]. Elevated HbA1c level is connected with excess hazard of new-onset and hospitalization for HF in patients with stable CAD [8], hospitalized and short-term mortality in acute coronary syndrome (ACS) without DM history and confirmed DM [9], all-cause mortality along with risk of myocardial infarction (MI) and HF in T2DM sufferers [10]. However, research findings at odds imply that intensive glucose control hasn't 
demonstrated significant effect on peril of HF or all-cause mortality in spite of risk reduction in macrovascular or coronary incidents [11, 12]. Moreover, it seems that intensive glucose lowering modality was associated with risk increase in congestive $\mathrm{HF}$ and non-significant impact on $\mathrm{Ml}$, and $\mathrm{HbA1c} \leq 7 \%$ even significantly raised mortality of advanced systolic HF with diabetes [13, 14]. These evidences remain contradictory regarding the role of $\mathrm{HbA} 1 \mathrm{c}$ level or glycemic administration in $\mathrm{HF}$ and myocardial ischemia related disorders.

In our prospective ischemic heart failure (IHF) cohort study among a Chinese population [15], we intended to identify all-cause mortality of IHF in relation to admission $\mathrm{HbA} 1 \mathrm{c}$ level, where sex- and age- related discrepancies were additionally explored, in consideration of sex differences in coronary heart disease (CHD) [16] and HF [17], and glucose targets varying from younger to elderly individuals recommended by current diabetes guidelines $[18,19]$.

\section{Methods}

\section{Study design and population}

Design of our single-center, prospective cohort study targeting IHF patients has been published previously [15]. Patients were selected who were hospitalized in the Department of Cardiology, Guangdong Provincial People's Hospital from December 2015 to June 2019. Eligible individuals were included with: a) $\geq 18$ years of age; $b$ ) left ventricular ejection fraction (LVEF) $<45 \%$ assessed by echocardiogram during hospitalization; c) IHD confirmed by coronary angiography, antecedent $\mathrm{MI}$, and/or antecedent revascularization; d) available $\mathrm{HbA} 1 \mathrm{c}$ data at admission. Patients were excluded with $\mathrm{LVEF}<45 \%$ due to non-ischemic etiologies or without any follow-up since discharge. This cohort study was approved by the Clinical Research Ethics Committee of Guangdong Provincial People's Hospital (No. 2017128H), as well as performed in accordance with the Declaration of Helsinki. All the participants provided written informed consent before enrollment.

\section{Data collection}

Baseline data of interest, including demographics, reasons for referral, vital sign at admission, comorbidities and hypoglycemic drugs, were obtained from electronic medical records of Guangdong Provincial People's Hospital. As described already [15], venous blood at admission was drawn for evaluation of $\mathrm{HbA} 1 \mathrm{c}$, creatinine, high-sensitivity $\mathrm{C}$-reactive protein (hs-CRP), high-sensitivity cardiac troponin-T (hs-cTnT) and N-terminal pro-brain natriuretic peptide (NT-proBNP) concentrations, and fasting venous blood was drawn for evaluation of fasting plasma glucose (FPG) and lipid parameters at the second day after admission. Morning urine was collected to examine urine albumin creatine ratio (UACR).

High-performance liquid chromatography (hemoglobin testing system D-10, Bio-Rad laboratories Inc, America) was utilized to test $\mathrm{HbA} 1 \mathrm{c}$ concentration. Body mass index (BMI) was calculated as body weight in kilogram divided by height in square meter. Diabetes status was defined according to diagnostic criteria of the American Diabetes Association (ADA) guideline [20]. Confirmed diabetes was 
defined as having been diagnosed diabetes priorly or two abnormal test results while in hospital (FPG $\geq 7.0 \mathrm{mmol} / \mathrm{L}$ and $\mathrm{HbA} 1 \mathrm{c} \geq 6.5 \%$ ). Pre-diabetes was defined as FPG levels from 5.6 to $6.9 \mathrm{mmol} / \mathrm{L}$ or $\mathrm{HbA} 1 \mathrm{c}$ levels from 5.7 to $6.4 \%$. Excluded diabetes was defined as the absence of prior diagnosis of diabetes and normal results of blood glucose and $\mathrm{HbA1c}$ during the current hospital visit. Undefined status was defined as not meeting the above conditions (for example, FPG $\geq 7.0 \mathrm{mmol} / \mathrm{L}$ while $\mathrm{HbA} 1 \mathrm{c}$ $<5.7 \%$ or $\mathrm{FPG}<7 \mathrm{mmol} / \mathrm{L}$ while $\mathrm{HbA} 1 \mathrm{c} \geq 6.5 \%$ ).

\section{Follow-up and clinical endpoint}

Methods of follow-up and clinical endpoint were presented previously [15]. Of note, all-cause mortality was served as clinical endpoint in the current study because of the unavailability of judgement for exact reasons of death.

\section{Statistical analysis}

Patients enrolled in the study were firstly divided into two groups based on $\mathrm{HbA} 1 \mathrm{c}$ concentrations ( $\mathrm{HbA} 1 \mathrm{c}$ $>7 \%$ and $\mathrm{HbA} 1 \mathrm{C} \leq 7 \%$ ). In addition, we analyzed the sex and age (age $\geq 65$ years old and age $<65$ years old) subgroups. Missing values of BMI, hs-CRP, hs-cTnT, NT-proBNP and UACR were filled by regression imputation. Continuous variables consistent with normal distribution were expressed as mean value \pm standard deviation (SD), while the data consistent with skewed distribution expressed as median (interquartile range) and categorical variables were expressed as number and proportion. A student's ttest or Mann-Whitney U-test was used to evaluate continuous variables properly, and chi-square test or Fisher's exact test was used to compare categorical variables. Differences in baseline characteristics were examined between $\mathrm{HbA} 1 \mathrm{c}>7 \%$ vs. $\mathrm{HbA} 1 \mathrm{c} \leq 7 \%$.

Univariate and multivariate logistic regression analyses were then performed to discover factors connected with $\mathrm{HbA} 1 \mathrm{c}>7 \%$. Briefly, factors with P-value $<0.1$ in univariate analysis were further included in multivariate analysis with stepwise adjustment. Odds ratio (OR) and $95 \%$ confidence interval (Cl) were recorded.

To determine the relationship between admission $\mathrm{HbA} 1 \mathrm{c}$ level and all-cause mortality in IHF patients as well as in the sex and age subgroups, survival analysis with Log-Rank test and multivariate Cox proportional hazards analysis with stepwise adjustment were performed for covariates including baseline characteristics, clinical presentations, antecedent medical histories, hypoglycemic agents and medications prescribed at discharge. Due to Kaplan-Meier survival curves of $\mathrm{HbA} 1 \mathrm{c}>7 \%$ and $\mathrm{HbA} 1 \mathrm{c} \leq 7 \%$ categories intersecting in the elderly subgroup, which means non-proportional risk model, time-dependent Cox regression analysis was then applied to identify the association between admission $\mathrm{HbA} 1 \mathrm{c}$ level and all-cause mortality of IHF in the elderly subgroup.

Sensitivity analysis was lastly employed to verify robustness of our results. There were 567 participants with missing values of $\mathrm{BMI}$ in our study owing to their serious illnesses, making them need to rest in bed and unable to measure height or weight. The remainder with BMI data were subsequently selected to 
explore the relationship between $\mathrm{HbA} 1 \mathrm{c}$ and all-cause mortality by survival analysis and multivariate Cox proportional hazards analysis. SPSS version 22.0 of Windows was utilized for all analyses, and two-sided P-value $<0.05$ was considered statistically significant.

\section{Results}

A total of $1520 \mathrm{IHF}$ patients with LVEF $<45 \%$ were included in the current cohort study. Among them, 83 patients lacked admission $\mathrm{HbA} 1 \mathrm{c}$ data and 24 patients were lost follow-up since discharge. The final cohort consisted of 1413 participants (Figure 1). The mean age was $63.2 \pm 10.9$ years old and $85.0 \%$ were men. The mean $\mathrm{HbA} 1 \mathrm{c}$ level was $6.8 \%$ and the mean FPG concentration was $6.17 \mathrm{mmol} / \mathrm{L}$. 529 patients (37.4\%) were confirmed diabetes, and 497 ones (35.2\%) were diagnosed pre-diabetes and 220 ones (15.6\%) excluded diabetes. The most commonly used hypoglycemic agents were a-glucosidase inhibitors (16.7\%), biguanides (11.7\%), sulfonylureas (7.6\%) and insulin (7.1\%), respectively.

\section{Baseline characteristics comparisons between $\mathrm{HbA} 1 \mathrm{c} \leq 7 \%$ and $\mathrm{HbA} 1 \mathrm{c}>7 \%$}

Table 1 presents baseline characteristics for all IHF individuals $(n=1413)$, ones with HbA1c $\leq 7 \%(n=981)$ and ones with $\mathrm{HbA} 1 \mathrm{c}>7 \%(\mathrm{n}=432)$. According to Table 1 , the majority of patients with $\mathrm{HbA} 1 \mathrm{c} \leq 7 \%$ were men and admitted for unstable angina, with lower heart rate and triglyceride (TG). Patients with HbA1c $>7 \%$ were mainly admitted for HF, and suffered from higher FPG, hs-cTnT, NT-proBNP, UACR and larger LA diameter. Approximately $70 \%$ of subjects received coronary stenting (69.2\% vs. $71.3 \%)$. More participants with $\mathrm{HbA} 1 \mathrm{c}>7 \%$ underwent intravenous diuretics and hypoglycemic agents in hospital, and were prescribed aspirin, mineralocorticoid receptor antagonists (MRA), loop diuretics and digoxin at discharge in comparison with those with $\mathrm{HbA} 1 \mathrm{c} \leq 7 \%$.

\section{Factors associated with $\mathrm{HbA} 1 \mathrm{c}>7 \%$ compared with $\mathrm{HbA} 1 \mathrm{c} \leq 7 \%$}

In the univariate analysis, factors associated with $\mathrm{HbA} 1 \mathrm{c}>7 \%$ comprised sex, $\mathrm{BMI}$, admission for ACS and HF, heart rate, FPG, hs-cTnT, NT-proBNP, high density lipoprotein cholesterol (HDL-C), TG and UACR. Multivariate regression analysis displayed that sex, FPG, HDL-C and UACR were linked with $\mathrm{HbA} 1 \mathrm{c}>7 \%$. To be specific, per $1 \mathrm{mmol} / \mathrm{L}$ increase in FPG (OR: 2.07, 95\% Cl: 1.71-2.51, $p=0.0001)$ and per $\log 10$ (UACR) $\mathrm{mg} / \mathrm{g} \mathrm{Cr}$ increase in UACR (OR: $1.86,95 \% \mathrm{Cl}: 1.25-2.76, \mathrm{p}=0.002$ ) were associated with $107 \%$ and $86 \%$ higher risks of $\mathrm{HbA} 1 \mathrm{c}>7 \%$. On the contrary, male sex (OR: $0.33,95 \% \mathrm{Cl}: 0.16-0.71, \mathrm{p}=0.004$ ) and elevated HDL-C concentrations (OR: $0.21,95 \% \mathrm{Cl}: 0.06-0.77, \mathrm{p}=0.018$ ) were more connected with HbA1c $\leq 7 \%$ (Table 2).

\section{Association between $\mathrm{HbA1c}$ and all-cause mortality in all patients}

After a median follow-up time of 2.9 years, 233 patients died with an overall mortality rate of $16.5 \%$ in the study cohort. Figure 2 shows higher hazard of death among those with admission $\mathrm{HbA} 1 \mathrm{c}>7 \%$, compared to ones with $\mathrm{HbA1c} \leq 7 \%$ (Log-Rank $\mathrm{p}=0.037$ ). Cox proportional hazards regression analysis showed that $\mathrm{HbA} 1 \mathrm{c}>7 \%$ was still associated with increased risk of all-cause mortality (HR: 1.330, 95\% Cl: 1.012-1.749, 
$p=0.041)$ after stepwise adjustment for baseline characteristics, clinical presentations, antecedent medical histories and medications prescribed at discharge. Other independent predictors of all-cause mortality included age, BMI, TG, LVEF, ST-segment elevation myocardial infarction (STEMI), prior stroke and tumor, aspirin therapy, beta-blockers (BB) therapy and diuretics therapy (Figure 3).

\section{Association between $\mathrm{HbA1c}$ and all-cause mortality in sex and age subgroups}

Figure $4 \mathrm{a}$ exhibits that male patients with admission $\mathrm{HbA} 1 \mathrm{c}>7 \%$ had higher hazard of all-cause mortality compared to those with $\mathrm{HbA} 1 \mathrm{c} \leq 7 \%$ (Log-Rank $\mathrm{p}=0.016)$. In the female population, linkage between $\mathrm{HbA1c}$ and all-cause mortality didn't reach statistical difference (Figure 4b). In multivariate Cox proportional hazards regression, male participants with $\mathrm{HbA} 1 \mathrm{c}>7 \%$ predicted greater risk of all-cause mortality (HR: $1.419,95 \% \mathrm{Cl}: 1.047-1.922, \mathrm{p}=0.024)$ in comparison to ones with $\mathrm{HbA} 1 \mathrm{c} \leq 7 \%$ (Figure $5 \mathrm{a}$ ).

Figure $4 c$ shows that all-cause mortality was significantly higher in the younger patients (age $<65 y e a r s$ old) with $\mathrm{HbA} 1 \mathrm{c}>7 \%$ compare to those with $\mathrm{HbA} 1 \mathrm{c} \leq 7 \%$ (Log-Rank $\mathrm{p}=0.002)$. In multivariate Cox proportional hazards regression, there was higher hazard of all-cause mortality in younger sufferers with $\mathrm{HbA1c}>7 \%$ (HR: 1.531, 95\% Cl: 1.014-2.312, $\mathrm{p}=0.043$ ) in contrast to ones with HbA1c $\leq 7 \%$ (Figure $5 b$ ). In the elderly cohort (age $\geq 65$ years old), Kaplan-Meier survival curves of $\mathrm{HbA} 1 \mathrm{c}>7 \%$ and $\mathrm{HbA} 1 \mathrm{c} \leq 7 \%$ intersected, meaning proportional hazards rate is violated. Hence, we implemented time-dependent Cox regression analysis instead of Cox proportional hazards model. Table 3 illustrates that in the timedependent Cox analysis, no significant effect of $\mathrm{HbA} 1 \mathrm{c}$ on all-cause mortality was observed in the elderly individuals.

\section{Sensitivity analysis}

In order to validate reliability of our results, we carried out sensitivity analysis in participants with available BMI data $(n=846)$. Supplementary Table 1 presents baseline characteristics between patients with BMI data and without BMI data. Those without BMI data seemed to experience more serious illnesses during hospitalization and need to rest in bed, leading to inability to measure height and weight. The results of sensitivity analysis were similar to those from the imputed data (Supplementary Figure 1 and Supplementary Figure 2). In patients with BMI data, $\mathrm{HbA} 1 \mathrm{c}>7 \%$ group suffered from greater risk of all-cause mortality compared with $\mathrm{HbA} 1 \mathrm{c} \leq 7 \%$ group (Log-Rank $\mathrm{p}=0.031$ ). Multivariate Cox proportional hazards regression illustrated that $\mathrm{HbA} 1 \mathrm{c}>7 \%$ remained predicting higher hazard of all-cause mortality than $\mathrm{HbA} 1 \mathrm{c} \leq 7 \%$ (HR: $1.552,95 \% \mathrm{Cl}: 1.086-2.218, \mathrm{p}=0.016)$.

\section{Discussion}

This prospective cohort study amongst a Chinese population with IHF denoted that higher level of admission $\mathrm{HbA} 1 \mathrm{c}$ ( $\mathrm{HbA} 1 \mathrm{c}>7 \%)$ was significantly associated with increased all-cause mortality in general IHF sufferers, which was likewise exhibited within male and younger individuals, with the absence of such relevance in female and elderly ones on the contrary. 
The present study primarily indicated that stringent glycemic administration (HbA1c $\leq 7 \%)$ facilitated reduction in risk of death and improved prognosis of general patients with IHF, conforming to glucose goals for a majority of DM subjects recommended by contemporary diabetes guidelines $[18,19]$. Diabetes contributes to structural cardiac alterations and HF partly via myocardial ischemia or infarction, where hyperglycemia and hyperinsulinemia escalate atherosclerosis [21]. HbA1c magnitude is positively correlated with coronary and peripheral atherosclerosis in non-diabetic population [22, 23], along with severity of coronary artery stenosis in acute myocardial infarction (AMI) with DM and non-DM [24]. Meanwhile, $\mathrm{HbA} 1 \mathrm{c}$ level is considered as one of the strongest predictors with regard to the peril of death, HF hospitalization and AMI amongst T2DM sufferers. Decreased HbA1c concentrations are linked with lower risks of these outcomes, more so of atherothrombotic incidents, even though $\mathrm{HbA} 1 \mathrm{c} \leq 7 \%$ marginally shrank risk of HF hospitalization [25]. Furthermore, some of AMI patients without known diabetes history have glucose metabolic disorders, and $\mathrm{HbA} 1 \mathrm{c} \geq 39 \mathrm{mmol} / \mathrm{mol}$ demonstrates a significant increase in risk of HF amongst those AMI subjects [26]. These findings, combined with our current study, inform detrimental effects of elevated $\mathrm{HbA} 1 \mathrm{c}$ level or hyperglycemia on $\mathrm{HF}$ and myocardial ischemia related alterations, and rigorous glycemic administration to achieve low $\mathrm{HbA} 1 \mathrm{c}$ targets predisposes patients with IHF to better outcomes.

As is known, hypoglycemia (sulfonylureas and insulin), fluid retention (thiazolidinediones), weight gain (sulfonylureas, insulin and thiazolidinediones) potentially prompt worsening in HF with certain hypoglycemic medications [7]. Intensively treated patients with poor prognosis of HF in the past studies $[13,14]$ are likely to encounter more adverse reactions on account of a greater amount of conventional antihyperglycemic drugs to reach lower $\mathrm{HbA1c}$ goals. Moreover, in the study where elevated $\mathrm{HbA} 1 \mathrm{c}$ level ameliorated survival of advanced systolic HF with diabetes, only 123 participants were involved, and ones with $\mathrm{HbA} 1 \mathrm{c}>7 \%$ had higher ejection fraction (EF) [14], signaling the requirement of involving more subjects and comparable baseline data between $\mathrm{HbA1c}$ groups. The exact connection between $\mathrm{HbA} 1 \mathrm{c}$ level and peril of IHF should be assessed by more research including randomized clinical trials.

With respect to sex-related disparities in linkage between death risk of IHF and $\mathrm{HbA} 1 \mathrm{c}$, our research implicated that $\mathrm{HbA} 1 \mathrm{c}$ showed positive relationship with all-cause mortality of IHF among male sufferers, while there was no significant difference for female ones. IHF subjects involved in our investigation were recognized with $\mathrm{LVEF}<45 \%$, which was defined as HF with reduced ejection fraction (HFrEF). Previous study found higher lifetime risk of HFrEF in men than women, and it might be attributed to men encountering heavier load and prior episode of CHD compared with women [27]. In addition, it's thought that HFrEF is predominantly a disease of men, where macrovascular lesions (e.g. CAD and MI) have been postulated to play a critical role, and conversely, women preponderate in HF with preserved ejection fraction (HFpEF), attributable to their susceptibility to coronary microvascular dysfunction and endothelial inflammation [17], although other research has demonstrated that lifetime risk of HFpEF was almost on a par between both sexes [27]. It can therefore be assumed that male individuals with HFrEF benefit more from strict glucose conduct in the setting of ischemic cardiomyopathy, whilst female ones 
fail to display the connection due to their predisposition to HFpEF and a paucity of adequate female participants ( $25 \%$ in our study).

Another notable indication in our results was that elevated level of $\mathrm{HbA1c}$ was linked with poor survival of IHF in the younger category (age $<65$ years old) rather than in the elderly category (age $\geq 65$ years old). It has previously been observed that risks of HF hospitalization, AMI and death related with diabetes illustrated a stepwise decline from younger to older age groups in the context of $\mathrm{HbA1c}$ beyond target range, and also of note, hazard of hospitalization for HF was not expected to shrink with $\mathrm{HbA} 1 \mathrm{c}$ not outside target range [25], which is not congruous with our outcome. What's more, preceding evidence suggests that younger sufferers aged $<55$ years with T2DM are susceptible to excessive risk of HF, of which excess risk declines with advancing age [28]. Intensive glucose lowering therapy significantly raises risk of hypoglycemia [11, 13], and diverse studies appear a consistently $U$ shaped relationship between $\mathrm{HbA} 1 \mathrm{c}$ and risk of death amongst $\mathrm{HF}$ subjects, with moderate $\mathrm{HbA} 1 \mathrm{c}$ level ( $7 \%$ to $8 \%$ ) conferring the lowest mortality [21]. Accordingly, up-to-date diabetes guidelines have recommended that more lenient $\mathrm{HbA} 1 \mathrm{c}$ goals may be suitable for individuals with limited life expectancy and severe comorbidities $[18,19]$. A plausible explanation for the results and evidence might be that there are greater potential benefits from more aggressive treatment on blood glucose for younger patients with IHF, whereas probable gains from lower admission $\mathrm{HbA} 1 \mathrm{c}$ level $(\leq 7 \%)$ across elderly ones are offset by deleterious impact of hypoglycemia.

Our observational investigation has several strengths and also some noteworthy limitations. Patients with HFrEF caused by ischemic cardiomyopathy or IHD in China were included. The positive association between admission $\mathrm{HbA} 1 \mathrm{c}$ magnitude and peril of $\mathrm{IHF}$ in the majority of population was substantiated. Nevertheless, this is a single center based and observational cohort study. More female participants are supposed to be incorporated to disclose the power of glucose control over prognosis of IHF in women. There was a comparatively small portion of application in novel glucose-lowering drugs in our participants, containing glucagon-like peptide-1 receptor agonists (GLP-1 RA), dipeptidyl peptidase-4 (DPP-4) inhibitors, and sodium-glucose cotransporter-2 (SGLT-2) inhibitors, signaling the need for more employment of these new therapies to recognize how drop in HbA1c contributed by them affects hazard of IHF.

In conclusion, elevated admission $\mathrm{HbA1c}$ level $(>7 \%)$ is an important indicator of increased all-cause mortality of IHF among general patients, and so for male and younger individuals. Further explorations are required to elucidate whether glycemic management plays a crucial role in the progression of IHF within female and elderly population.

\section{Abbreviations}

$\mathrm{HbA1c}$, hemoglobin A1c; HF, heart failure; IHD, ischemic heart disease; IHF, ischemic heart failure; HR, hazard ratio; $\mathrm{Cl}$, confidence interval; IGT, impaired glucose tolerance; T2DM, type 2 diabetes mellitus; DM, diabetes mellitus; CAD, coronary artery disease; ACS, acute coronary syndrome; MI, myocardial infarction; 
CHD, coronary heart disease; LVEF, left ventricular ejection fraction; hs-CRP, high-sensitivity C-reactive protein; hs-cTnT, high-sensitivity cardiac troponin-T; NT-proBNP, N-terminal pro-brain natriuretic peptide; FPG, fasting plasma glucose; UACR, urine albumin creatine ratio; BMI, body mass index; ADA, American Diabetes Association; SD, standard deviation; OR, odds ratio; TG, triglyceride; MRA, mineralocorticoid receptor antagonists; $\mathrm{HDL}-\mathrm{C}$, high density lipoprotein cholesterol; STEMI, ST-segment elevation myocardial infarction; $\mathrm{BB}$, beta-blockers; $\mathrm{AMI}$, acute myocardial infarction; $\mathrm{EF}$, ejection fraction; $\mathrm{HFrEF,} \mathrm{HF}$ with reduced ejection fraction; HFpEF, HF with preserved ejection fraction; GLP1 RA, glucagon-like peptide1 receptor agonists; DPP-4, dipeptidyl peptidase-4; SGLT2, sodium-glucose cotransporter-2.

\section{Declarations}

\section{Ethics approval and consent to participate}

The Clinical Research Ethics Committee of Guangdong Provincial People's Hospital approved the study protocol (No. 2017128H) in accordance with the Declaration of Helsinki, and written informed consent was obtained from all participants.

\section{Consent for publication}

The manuscript was approved by all authors for publication.

\section{Availability of data and materials}

The datasets used and analyzed during the current study are available from the corresponding author on reasonable request.

\section{Competing interests}

All authors declare that they have no competing interests.

\section{Funding}

This study was supported by the Guangzhou Science and Technology Program (No. 202002030088).

\section{Authors' contributions}

QWD contributed to the data collection, analysis and drafted the manuscript. CSC drafted the manuscript. CAP critically revised the manuscript. XXJ contributed to the data collection. GZP, LJJ and LLW contributed to the conception and design of the work. All authors read and approved the final manuscript.

\section{Corresponding author}

Correspondence to Jijin Lin and Liwen Li.

\section{Acknowledgements}


Not appliable.

\section{References}

1. Virani SS, Alonso A, Benjamin EJ, Bittencourt MS, Callaway CW, Carson AP, Chamberlain AM, Chang AR, Cheng S, Delling FN, et al. Heart Disease and Stroke Statistics-2020 Update: A Report From the American Heart Association. Circulation. 2020;141(9):e139-596.

2. Jones NR, Roalfe AK, Adoki I, Hobbs FDR, Taylor CJ. Survival of patients with chronic heart failure in the community: a systematic review and meta-analysis. Eur J Heart Fail. 2019;21(11):1306-25.

3. Saeedi P, Petersohn I, Salpea P, Malanda B, Karuranga S, Unwin N, Colagiuri S, Guariguata L, Motala AA, Ogurtsova $\mathrm{K}$, et al: Global and regional diabetes prevalence estimates for 2019 and projections for 2030 and 2045: Results from the International Diabetes Federation Diabetes Atlas, 9(th) edition. Diabetes Res Clin Pract 2019, 157:107843.

4. Seferović PM, Petrie MC, Filippatos GS, Anker SD, Rosano G, Bauersachs J, Paulus WJ, Komajda M, Cosentino F, de Boer RA, et al. Type 2 diabetes mellitus and heart failure: a position statement from the Heart Failure Association of the European Society of Cardiology. Eur J Heart Fail. 2018;20(5):853-72.

5. Dries DL, Sweitzer NK, Drazner MH, Stevenson LW, Gersh BJ. Prognostic impact of diabetes mellitus in patients with heart failure according to the etiology of left ventricular systolic dysfunction. $J$ Am Coll Cardiol. 2001;38(2):421-8.

6. Johansson I, Dahlström U, Edner M, Näsman P, Rydén L, Norhammar A. Prognostic Implications of Type 2 Diabetes Mellitus in Ischemic and Nonischemic Heart Failure. J Am Coll Cardiol. 2016;68(13):1404-16.

7. Davies MJ, D'Alessio DA, Fradkin J, Kernan WN, Mathieu C, Mingrone G, Rossing P, Tsapas A, Wexler DJ, Buse JB. Management of Hyperglycemia in Type 2 Diabetes, 2018. A Consensus Report by the American Diabetes Association (ADA) and the European Association for the Study of Diabetes (EASD). Diabetes Care. 2018;41(12):2669-701.

8. van Melle JP, Bot M, de Jonge P, de Boer RA, van Veldhuisen DJ, Whooley MA. Diabetes, glycemic control, and new-onset heart failure in patients with stable coronary artery disease: data from the heart and soul study. Diabetes Care. 2010;33(9):2084-9.

9. Pan W, Lu H, Lian B, Liao P, Guo L, Zhang M. Prognostic value of HbA1c for in-hospital and shortterm mortality in patients with acute coronary syndrome: a systematic review and meta-analysis. Cardiovasc Diabetol. 2019;18(1):169.

10. Stratton IM, Adler AI, Neil HA, Matthews DR, Manley SE, Cull CA, Hadden D, Turner RC, Holman RR. Association of glycaemia with macrovascular and microvascular complications of type 2 diabetes (UKPDS 35): prospective observational study. Bmj. 2000;321(7258):405-12.

11. Turnbull FM, Abraira C, Anderson RJ, Byington RP, Chalmers JP, Duckworth WC, Evans GW, Gerstein HC, Holman RR, Moritz TE, et al. Intensive glucose control and macrovascular outcomes in type 2 
diabetes. Diabetologia. 2009;52(11):2288-98.

12. Ray KK, Seshasai SR, Wijesuriya S, Sivakumaran R, Nethercott S, Preiss D, Erqou S, Sattar N. Effect of intensive control of glucose on cardiovascular outcomes and death in patients with diabetes mellitus: a meta-analysis of randomised controlled trials. Lancet. 2009;373(9677):1765-72.

13. Boussageon R, Bejan-Angoulvant T, Saadatian-Elahi M, Lafont S, Bergeonneau C, Kassaï B, Erpeldinger S, Wright JM, Gueyffier F, Cornu C. Effect of intensive glucose lowering treatment on all cause mortality, cardiovascular death, and microvascular events in type 2 diabetes: meta-analysis of randomised controlled trials. Bmj. 2011;343:d4169.

14. Eshaghian S, Horwich TB, Fonarow GC. An unexpected inverse relationship between HbA1c levels and mortality in patients with diabetes and advanced systolic heart failure. Am Heart J. 2006;151(1):91.

15. Cai A, Wu Z, Xu L, Xia S, He X, Zhang Y, Chen J, Zhou Y, Li L. Association of anaemia and all-cause mortality in patients with ischaemic heart failure varies by renal function status. ESC Heart Fail. 2021;8(3):2270-81.

16. Shah AD, Langenberg C, Rapsomaniki E, Denaxas S, Pujades-Rodriguez M, Gale CP, Deanfield J, Smeeth L, Timmis A, Hemingway $\mathrm{H}$. Type 2 diabetes and incidence of cardiovascular diseases: a cohort study in 1.9 million people. Lancet Diabetes Endocrinol. 2015;3(2):105-13.

17. Lam CSP, Arnott C, Beale AL, Chandramouli C, Hilfiker-Kleiner D, Kaye DM, Ky B, Santema BT, Sliwa K, Voors AA. Sex differences in heart failure. Eur Heart J. 2019;40(47):3859-68c.

18. Cosentino F, Grant PJ, Aboyans V, Bailey CJ, Ceriello A, Delgado V, Federici M, Filippatos G, Grobbee DE, Hansen TB, et al. 2019 ESC Guidelines on diabetes, pre-diabetes, and cardiovascular diseases developed in collaboration with the EASD. Eur Heart J. 2020;41(2):255-323.

19. 6. Glycemic Targets: Standards of Medical Care in Diabetes-2021. Diabetes Care 2021, 44(Suppl 1):S73-s84.

20. 2. Classification and Diagnosis of Diabetes: Standards of Medical Care in Diabetes-2021. Diabetes Care 2021, 44(Suppl 1):S15-s33.

21. Dunlay SM, Givertz MM, Aguilar D, Allen LA, Chan M, Desai AS, Deswal A, Dickson VV, Kosiborod MN, Lekavich CL, et al. Type 2 Diabetes Mellitus and Heart Failure: A Scientific Statement From the American Heart Association and the Heart Failure Society of America: This statement does not represent an update of the 2017 ACC/AHA/HFSA heart failure guideline update. Circulation. 2019;140(7):e294-324.

22. Haring R, Baumeister SE, Lieb W, von Sarnowski B, Völzke H, Felix SB, Nauck M, Wallaschofski H. Glycated hemoglobin as a marker of subclinical atherosclerosis and cardiac remodeling among nondiabetic adults from the general population. Diabetes Res Clin Pract. 2014;105(3):416-23.

23. Scicali R, Giral P, Gallo A, Di Pino A, Rabuazzo AM, Purrello F, Cluzel P, Redheuil A, Bruckert E, Rosenbaum D. HbA1c increase is associated with higher coronary and peripheral atherosclerotic burden in non diabetic patients. Atherosclerosis. 2016;255:102-8. 
24. She J, Deng Y, Wu Y, Xia Y, Li H, Liang X, Shi R, Yuan Z. Hemoglobin A(1c) is associated with severity of coronary artery stenosis but not with long term clinical outcomes in diabetic and nondiabetic patients with acute myocardial infarction undergoing primary angioplasty. Cardiovasc Diabetol. 2017;16(1):97.

25. Rawshani A, Rawshani A, Franzén S, Sattar N, Eliasson B, Svensson AM, Zethelius B, Miftaraj M, McGuire DK, Rosengren A, et al. Risk Factors, Mortality, and Cardiovascular Outcomes in Patients with Type 2 Diabetes. N Engl J Med. 2018;379(7):633-44.

26. Karayiannides S, Djupsjö C, Kuhl J, Hofman-Bang C, Norhammar A, Holzmann MJ, Lundman P. Longterm prognosis in patients with acute myocardial infarction and newly detected glucose abnormalities: predictive value of oral glucose tolerance test and HbA1c. Cardiovasc Diabetol. 2021;20(1):122.

27. Pandey A, Omar W, Ayers C, LaMonte M, Klein L, Allen NB, Kuller LH, Greenland P, Eaton CB, Gottdiener JS, et al. Sex and Race Differences in Lifetime Risk of Heart Failure With Preserved Ejection Fraction and Heart Failure With Reduced Ejection Fraction. Circulation. 2018;137(17):181423.

28. Rosengren A, Edqvist J, Rawshani A, Sattar N, Franzén S, Adiels M, Svensson AM, Lind M, Gudbjörnsdottir S. Excess risk of hospitalisation for heart failure among people with type 2 diabetes. Diabetologia. 2018;61(11):2300-9.

\section{Tables}

Table 1. Baseline Characteristics Comparisons between $\mathrm{HbA} 1 \mathrm{c} \leq 7.0 \%$ and $\mathrm{HbA} 1 \mathrm{c}>7.0 \%$. 


\begin{tabular}{|c|c|c|c|c|}
\hline Variables & $\begin{array}{l}\text { Overall } \\
(n=1413)\end{array}$ & $\begin{array}{l}\text { HbA1c } \leq 7.0 \% \\
(n=981)\end{array}$ & $\begin{array}{l}\mathrm{HbA} 1 \mathrm{c}>7.0 \% \\
(\mathrm{n}=432)\end{array}$ & $\begin{array}{l}\mathrm{P}- \\
\text { value }\end{array}$ \\
\hline Age(years) & $63.2 \pm 10.9$ & $63.5 \pm 11.3$ & $62.6 \pm 10.0$ & 0.123 \\
\hline Male, $n(\%)$ & $1201(85.0)$ & $852(86.9)$ & $349(80.8)$ & 0.003 \\
\hline BMI (kg/m2) & $23.6 \pm 3.3$ & $23.5 \pm 3.4$ & $23.9 \pm 3.1$ & 0.058 \\
\hline \multicolumn{5}{|l|}{ Reasons for referral } \\
\hline STEMI, n (\%) & $230(16.3)$ & $162(16.5)$ & $68(15.7)$ & 0.717 \\
\hline Non-STEMI, n (\%) & $112(7.9)$ & $72(7.3)$ & $40(9.3)$ & 0.218 \\
\hline Unstable angina, n (\%) & $633(44.8)$ & $468(47.7)$ & $165(38.2)$ & 0.001 \\
\hline Heart failure, n (\%) & $407(28.8)$ & $255(26.0)$ & $152(35.2)$ & $<0.001$ \\
\hline Others, n (\%) & $31(2.2)$ & $24(2.4)$ & $7(1.6)$ & 0.431 \\
\hline \multicolumn{5}{|l|}{ Vital sign at admission } \\
\hline $\mathrm{SBP}(\mathrm{mmHg})$ & $125 \pm 20$ & $125 \pm 20$ & $126 \pm 20$ & 0.594 \\
\hline $\mathrm{DBP}(\mathrm{mmHg})$ & $75 \pm 12$ & $75 \pm 13$ & $75 \pm 12$ & 0.798 \\
\hline HR (bpm) & $80 \pm 15$ & $79 \pm 15$ & $83 \pm 15$ & $<0.001$ \\
\hline \multicolumn{5}{|l|}{ Diabetic status } \\
\hline Confirmed diabetes, n (\%) & $529(37.4)$ & $159(16.2)$ & $370(85.6)$ & $<0.001$ \\
\hline Pre-diabetes, n (\%) & $497(35.2)$ & $497(50.7)$ & $0(0)$ & $<0.001$ \\
\hline Excluded diabetes, n (\%) & $220(15.6)$ & $220(22.4)$ & $0(0)$ & $<0.001$ \\
\hline Undefined, n (\%) & $167(11.8)$ & $105(10.7)$ & $62(14.4)$ & $<0.001$ \\
\hline \multicolumn{5}{|l|}{ Comorbid conditions } \\
\hline Smoking, n (\%) & $343(24.2)$ & $252(25.7)$ & $91(21.1)$ & 0.062 \\
\hline Obesity, n (\%) & $63(4.5)$ & $39(4.0)$ & $24(5.6)$ & 0.185 \\
\hline Hypertension, n (\%) & $729(51.6)$ & $504(51.4)$ & $225(52.1)$ & 0.806 \\
\hline Dyslipidemia, n (\%) & $888(62.8)$ & $611(62.3)$ & $277(64.1)$ & 0.510 \\
\hline Atrial fibrillation, n (\%) & $90(6.4)$ & $62(6.3)$ & $28(6.5)$ & 0.909 \\
\hline Prior stroke/TIA, n (\%) & $110(7.8)$ & $79(8.1)$ & $31(7.2)$ & 0.571 \\
\hline COPD, n (\%) & $107(7.6)$ & $77(7.8)$ & $30(6.9)$ & 0.554 \\
\hline Prior tumor, n (\%) & $19(1.3)$ & $18(1.8)$ & $1(0.2)$ & 0.002 \\
\hline
\end{tabular}




\begin{tabular}{|c|c|c|c|c|}
\hline Prior MI, n (\%) & $498(35.2)$ & $351(35.8)$ & $147(34.0)$ & 0.525 \\
\hline Prior PCl, n (\%) & $818(57.9)$ & $559(57.0)$ & $259(60.0)$ & 0.297 \\
\hline Prior CABG, n (\%) & $26(1.8)$ & $15(1.5)$ & $11(2.5)$ & 0.201 \\
\hline \multicolumn{5}{|l|}{ Laboratory } \\
\hline HbA1C (\%) & $6.82 \pm 1.64$ & $5.94 \pm 0.56$ & $8.84 \pm 1.47$ & $<0.001$ \\
\hline FPG (mmol/L) & $6.17 \pm 2.54$ & $5.29 \pm 1.31$ & $8.22 \pm 3.41$ & $<0.001$ \\
\hline Hemoglobin (mg/dL) & $131.8 \pm 19.1$ & $132.3 \pm 18.7$ & $130.6 \pm 19.9$ & 0.126 \\
\hline Creatinine ( $\mu \mathrm{mol} / \mathrm{L})$ & $105.1 \pm 74.3$ & $105.3 \pm 73.8$ & $104.8 \pm 75.5$ & 0.917 \\
\hline eGFR (ml/min/1.73m²) & $72.93 \pm 22.35$ & $72.82 \pm 21.77$ & $73.19 \pm 23.64$ & 0.778 \\
\hline $\mathrm{Hs}-\mathrm{CRP}(\mathrm{mg} / \mathrm{L})$ * & $\begin{array}{l}5.06(1.41- \\
15.25)\end{array}$ & $5.06(1.33-16.38)$ & $5.19(1.53-14.40)$ & 0.735 \\
\hline Hs-cTnT (pg/mL) * & $\begin{array}{l}36.82(18- \\
229.3)\end{array}$ & $32.2(17.0-186.8)$ & $47.4(21.8-310.4)$ & $<0.001$ \\
\hline NT-proBNP $(\mathrm{pg} / \mathrm{mL})$ * & $\begin{array}{l}1608(648 \\
-3606)\end{array}$ & $1492(593-3206)$ & 1834 (777-4447) & $<0.001$ \\
\hline $\mathrm{TC}(\mathrm{mmol} / \mathrm{L})$ & $4.39 \pm 1.32$ & $4.42 \pm 1.32$ & $4.35 \pm 1.31$ & 0.369 \\
\hline LDL-C (mmol/L) & $2.88 \pm 1.01$ & $2.89 \pm 1.03$ & $2.86 \pm 0.97$ & 0.510 \\
\hline $\mathrm{HDL}-\mathrm{C}(\mathrm{mmol} / \mathrm{L})$ & $0.94 \pm 0.24$ & $0.95 \pm 0.24$ & $0.91 \pm 0.24$ & 0.004 \\
\hline $\mathrm{TG}(\mathrm{mmol} / \mathrm{L})$ * & $\begin{array}{l}1.30(0.99- \\
1.78)\end{array}$ & $1.24(0.98-1.71)$ & $1.46(1.05-1.98)$ & $<0.001$ \\
\hline UACR (mg/g Cr) * & $\begin{array}{l}8.85(3.93- \\
45.04)\end{array}$ & $6.16(3.32-29.01)$ & $\begin{array}{l}21.93(7.12- \\
108.04)\end{array}$ & $<0.001$ \\
\hline \multicolumn{5}{|l|}{ Echocardiographic indices } \\
\hline LVEF (\%) & $35.00 \pm 6.90$ & $35.17 \pm 6.90$ & $34.62 \pm 6.90$ & 0.167 \\
\hline LVEF $\leq \mathbf{4 0 \%}$, n (\%) & $1069(75.7)$ & $568(74.6)$ & $501(76.8)$ & 0.336 \\
\hline \multicolumn{5}{|l|}{ In-hospital treatment } \\
\hline Coronary stenting, n (\%) & $987(69.9)$ & $679(69.2)$ & 308 (71.3) & 0.432 \\
\hline IV inotrope, $\mathrm{n}(\%)$ & $173(12.2)$ & $112(11.4)$ & $61(14.1)$ & 0.153 \\
\hline IV diuretics, n (\%) & $508(36.0)$ & $323(32.9)$ & $185(42.8)$ & $<0.001$ \\
\hline \multicolumn{5}{|l|}{ Hypoglycemic agents } \\
\hline Sulfonylureas, n (\%) & $108(7.6)$ & $38(3.9)$ & 70 (16.2) & $<0.001$ \\
\hline Biguanides, n (\%) & $166(11.7)$ & $39(4.0)$ & $127(29.4)$ & $<0.001$ \\
\hline
\end{tabular}




\begin{tabular}{|c|c|c|c|c|}
\hline $\begin{array}{l}\text { a-glucosidase inhibitors, n } \\
\text { (\%) }\end{array}$ & $236(16.7)$ & $72(7.3)$ & $164(38.0)$ & $<0.001$ \\
\hline Thiazolidinediones, n (\%) & $6(0.4)$ & $4(0.4)$ & $2(0.5)$ & 1.00 \\
\hline Glinides, n (\%) & $32(2.3)$ & $10(1.0)$ & $22(5.1)$ & $<0.001$ \\
\hline $\begin{array}{l}\text { GLP-1 receptor agonists, } n \\
\text { (\%) }\end{array}$ & $2(0.1)$ & $0(0)$ & $2(0.5)$ & 0.093 \\
\hline $\begin{array}{l}\text { DPP-4 enzyme inhibitors, n } \\
\text { (\%) }\end{array}$ & $30(2.1)$ & $5(0.5)$ & $25(5.8)$ & $<0.001$ \\
\hline SGLT2i, n (\%) & $2(0.1)$ & $0(0)$ & $2(0.5)$ & 0.093 \\
\hline Insulin, n (\%) & $100(7.1)$ & $13(1.3)$ & $88(20.4)$ & $<0.001$ \\
\hline \multicolumn{5}{|c|}{ Medications prescribed at discharge } \\
\hline Aspirin, n (\%) & $1263(89.4)$ & $866(88.3)$ & $397(91.9)$ & 0.042 \\
\hline Clopidogrel, n (\%) & $1053(74.5)$ & $726(74.0)$ & $327(75.7)$ & 0.502 \\
\hline Ticagrelor, n (\%) & $182(12.9)$ & $123(12.5)$ & $59(13.7)$ & 0.563 \\
\hline Statins, n (\%) & $1341(94.9)$ & $933(95.1)$ & $408(94.4)$ & 0.602 \\
\hline RASi, n (\%) & $1001(70.8)$ & $694(70.7)$ & $307(71.1)$ & 0.903 \\
\hline ARNI, n (\%) & $39(2.8)$ & $25(2.5)$ & $14(3.2)$ & 0.483 \\
\hline MRA, n (\%) & $720(51.0)$ & $466(47.5)$ & $254(58.8)$ & $<0.001$ \\
\hline CCB, n (\%) & $137(9.7)$ & $100(10.2)$ & $37(8.6)$ & 0.340 \\
\hline Betablocker, n (\%) & $1199(84.9)$ & $829(84.5)$ & $370(85.6)$ & 0.581 \\
\hline Diuretics, n (\%) & $680(48.1)$ & $441(45.0)$ & $239(55.3)$ & $<0.001$ \\
\hline Digoxin, n (\%) & $102(7.2)$ & $61(6.2)$ & $41(9.5)$ & 0.029 \\
\hline Oral anticoagulants, $n(\%)$ & $98(6.9)$ & $68(6.9)$ & $30(6.9)$ & 0.993 \\
\hline
\end{tabular}

HbA1c, hemoglobin A1c; BMI, body Mass Index; STENI, ST-segment elevation myocardial infarction; NonSTEMI, Non-ST-segment elevation myocardial infarction; SBP, systolic blood pressure; DBP, diastolic blood pressure; HR, heart rate; bpm, beat per minute; TIA, transient ischemic attack; COPD, chronic obstructive pulmonary disease; $\mathrm{MI}$, myocardial infarction; $\mathrm{PCl}$, percutaneous coronary intervention; $\mathrm{CABG}$, coronary artery bypass grafting; FPG, fasting plasma glucose; eGFR, estimated glomerular filtration rate; Hs-CRP, high sensitivity $\mathrm{C}$ reactive protein; $\mathrm{Hs-cTnT}$, high sensitivity cardiac troponin-T; NT-proBNP, N-terminal pro B-type natriuretic peptide; TC, total cholesterol; LDL-C, low density lipoprotein-cholesterol; HDL-C, high density lipoprotein cholesterol; TG, triglyceride; UACR, urine albumin creatine ratio; LVEF, left ventricular ejection fraction; IV, intravenous; GLP-1, Glucagon-likepeptide-1; DPP-4, dipeptidyl peptidase-4; SGLT2i, sodium-dependent glucose transporters 2 inhibitor; RASi, renin-angiotensin-system inhibitor; ARNI, 
angiotensin receptor-neprilysin inhibitor; MRA, mineralocorticoid receptor antagonist; $\mathrm{CCB}$, calcium channel blocker.

Table 2 Factors associated with $\mathrm{HbA} 1 \mathrm{C} \otimes 7.0 \%$ compared to $\mathrm{HbA} 1 \mathrm{C} \leq 7.0 \%$. 


\begin{tabular}{|c|c|c|c|c|}
\hline & Univariate & & Multivariable & \\
\hline Variables & OR $(95 \% \mathrm{Cl})$ & P-value & OR $(95 \% \mathrm{Cl})$ & P-value \\
\hline Age (per 1-year increase) & $\begin{array}{l}0.99(0.98- \\
1.00)\end{array}$ & 0.141 & N/A & \\
\hline Men vs women & $\begin{array}{l}0.64(0.47- \\
0.86)\end{array}$ & 0.003 & $\begin{array}{l}0.33(0.16- \\
0.71)\end{array}$ & 0.004 \\
\hline BMI (per $1-\mathrm{kg} / \mathrm{m}^{2}$ increase) & $\begin{array}{l}1.04(1.00- \\
1.09)\end{array}$ & 0.058 & $\begin{array}{l}0.97(0.89- \\
1.06)\end{array}$ & 0.547 \\
\hline ACS vs non-ACS & $\begin{array}{l}0.68(0.54- \\
0.87)\end{array}$ & 0.002 & $\begin{array}{l}0.17(0.03- \\
1.11)\end{array}$ & 0.064 \\
\hline HF vs non-HF & $\begin{array}{l}1.55(1.21- \\
1.97)\end{array}$ & $<0.0001$ & $\begin{array}{l}0.22(0.03- \\
1.58)\end{array}$ & 0.132 \\
\hline SBP (per 1-mmHg increase) & $\begin{array}{l}1.00(1.00- \\
1.01)\end{array}$ & 0.593 & N/A & \\
\hline DBP (per 1-mmHg increase) & $\begin{array}{l}1.00(0.99- \\
1.01)\end{array}$ & 0.798 & N/A & \\
\hline Heart rate (per 1-bpm increase) & $\begin{array}{l}1.02(1.01- \\
1.03)\end{array}$ & $<0.0001$ & $\begin{array}{l}1.00(0.98- \\
1.02)\end{array}$ & 0.879 \\
\hline Smoking vs non-smoking & $\begin{array}{l}1.09(0.72- \\
1.64)\end{array}$ & 0.683 & N/A & \\
\hline Hypertension vs non-hypertension & $\begin{array}{l}1.03(0.82- \\
1.29)\end{array}$ & 0.806 & N/A & \\
\hline Dyslipidemia vs non-dyslipidemia & $\begin{array}{l}1.08(0.86- \\
1.37)\end{array}$ & 0.510 & N/A & \\
\hline COPD vs non-COPD & $\begin{array}{l}0.88(0.57- \\
1.36)\end{array}$ & 0.554 & N/A & \\
\hline AF vs non-AF & $\begin{array}{l}1.03(0.65- \\
1.63)\end{array}$ & 0.909 & N/A & \\
\hline Prior stroke/TIA vs non- prior stroke/TIA & $\begin{array}{l}0.88(0.57- \\
1.36)\end{array}$ & 0.571 & N/A & \\
\hline Prior MI vs non-prior MI & $\begin{array}{l}0.93(0.73- \\
1.18)\end{array}$ & 0.525 & N/A & \\
\hline Prior $\mathrm{PCl}$ vs non-prior $\mathrm{PCl}$ & $\begin{array}{l}1.13(0.90- \\
1.42)\end{array}$ & 0.297 & N/A & \\
\hline Prior CABG vs non-prior CABG & $\begin{array}{l}1.68(0.77- \\
3.69)\end{array}$ & 0.195 & N/A & \\
\hline Hemoglobin (per 1-mg/dL increase) & $\begin{array}{l}1.00(0.99- \\
1.00)\end{array}$ & 0.126 & N/A & \\
\hline
\end{tabular}




\begin{tabular}{|c|c|c|c|c|}
\hline FPG (per 1-mmol/L increase) & $\begin{array}{l}1.96(1.78- \\
2.15)\end{array}$ & $<0.0001$ & $\begin{array}{l}2.07(1.71- \\
2.51)\end{array}$ & $<0.0001$ \\
\hline TC (per 1-mmol/L increase) & $\begin{array}{l}0.96(0.88- \\
1.05)\end{array}$ & 0.369 & N/A & \\
\hline LDL-C (per 1-mmol/L increase) & $\begin{array}{l}0.96(0.86- \\
1.08)\end{array}$ & 0.510 & N/A & \\
\hline HDL-C (per 1-mmol/L increase) & $\begin{array}{l}0.49(0.30- \\
0.80)\end{array}$ & 0.004 & $\begin{array}{l}0.21(0.06- \\
0.77)\end{array}$ & 0.018 \\
\hline TG (per 1-mmol/L increase) & $\begin{array}{l}1.23(1.10- \\
1.38)\end{array}$ & $<0.0001$ & $\begin{array}{l}1.06(0.85- \\
1.33)\end{array}$ & 0.589 \\
\hline eGFR (per $1-\mathrm{ml} / \mathrm{min} / 1.73 \mathrm{~m}^{2}$ increase) & $\begin{array}{l}1.00(1.00- \\
1.01)\end{array}$ & 0.771 & N/A & \\
\hline Hs-CRP (per log10(hs-CRP) mg/L increase) & $\begin{array}{l}1.04(0.84- \\
1.27)\end{array}$ & 0.733 & N/A & \\
\hline $\begin{array}{l}\text { Hs-cTNT (per log10(hs-cTNT) pg/mL } \\
\text { increase) }\end{array}$ & $\begin{array}{l}1.19(1.04- \\
1.38)\end{array}$ & 0.014 & $\begin{array}{l}1.19(0.78- \\
1.83)\end{array}$ & 0.416 \\
\hline $\begin{array}{l}\text { NT-proBNP (per log10(NT-proBNP) pg/mL } \\
\text { increase) }\end{array}$ & $\begin{array}{l}1.52(1.23- \\
1.89)\end{array}$ & $<0.0001$ & $\begin{array}{l}0.73(0.37- \\
1.46)\end{array}$ & 0.377 \\
\hline UACR (per log10(UACR) mg/g Cr increase) & $\begin{array}{l}2.16(1.74- \\
2.69)\end{array}$ & $<0.0001$ & $\begin{array}{l}1.86(1.25- \\
2.76)\end{array}$ & 0.002 \\
\hline
\end{tabular}

$\mathrm{HbA1C}$, hemoglobin A1c; BMI, body Mass Index; ACS, acute coronary syndrome; HF, heart failure; SBP, systolic blood pressure; DBP, diastolic blood pressure; bpm, beat per minute; COPD, chronic obstructive pulmonary disease; $\mathrm{AF}$, atrial fibrillation; TIA, transient ischemic attack; $\mathrm{Ml}$, myocardial infarction; $\mathrm{PCl}$, percutaneous coronary intervention; $C A B G$, coronary artery bypass grafting; FPG, fasting plasma glucose; TC, total cholesterol; LDL-C, low density lipoprotein-cholesterol; HDL-C, high density lipoprotein cholesterol; TG, triglyceride; eGFR, estimated glomerular filtration rate; Hs-CRP, high sensitivity $\mathrm{C}$ reactive protein; Hs-cTnT, high sensitivity cardiac troponin-T; NT-proBNP, N-terminal pro B-type natriuretic peptide; UACR, urine albumin creatine ratio.

Table 3. Time-dependent Cox's regression analysis in elderly cohort.

\begin{tabular}{|lllll|}
\hline & Wald & HR & $95 \% \mathrm{Cl}$ & p-value \\
\hline HbA1C & 1.199 & 1.330 & $0.798,2.217$ & 0.273 \\
$(>7 \%$ VS $\leq 7 \%)$ & & & & \\
\hline Time-covariate & 166.817 & 0.143 & $0.106,0.192$ & $<0.001$ \\
\hline
\end{tabular}

\section{Figures}




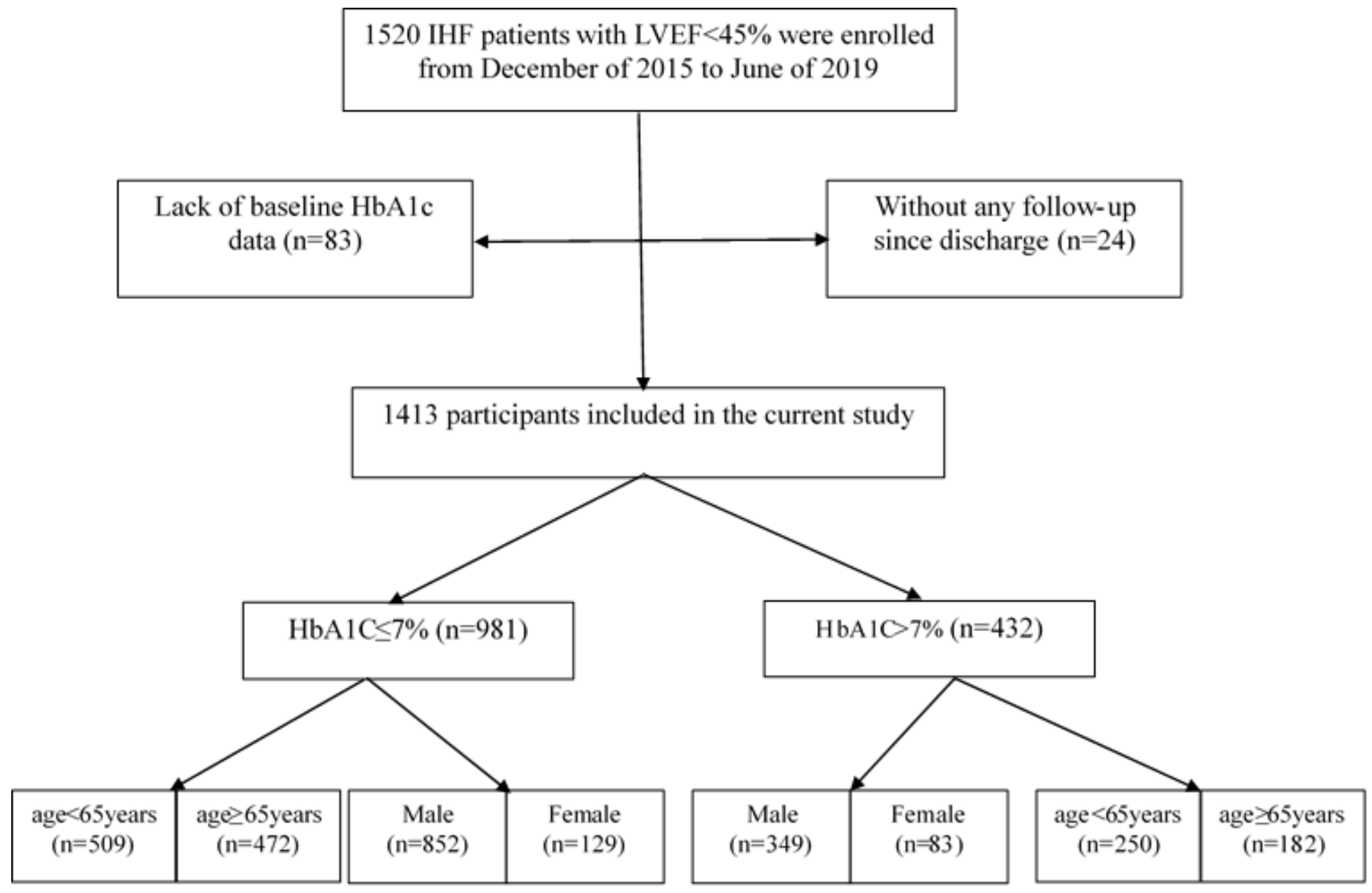

Figure 1

Study flowchart IHF, ischemic heart failure; LVEF, left ventricular ejection fraction; HbA1C, hemoglobin A1c.

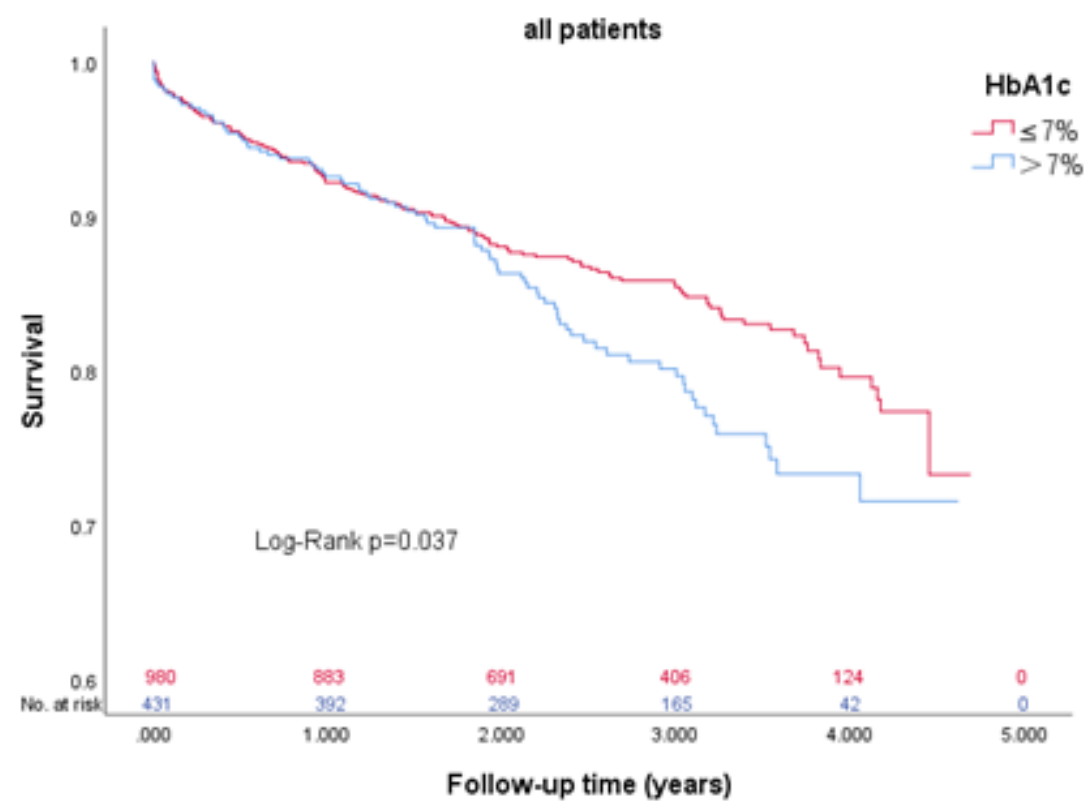

Figure 2 
Kaplan-Meier survival curves of patients with $\mathrm{HbA} 1 \mathrm{c} \leq 7 \%$ versus $\mathrm{HbA} 1 \mathrm{c} \otimes 7 \%$.

multivariable Cox proportional

hazard analysis in overall population

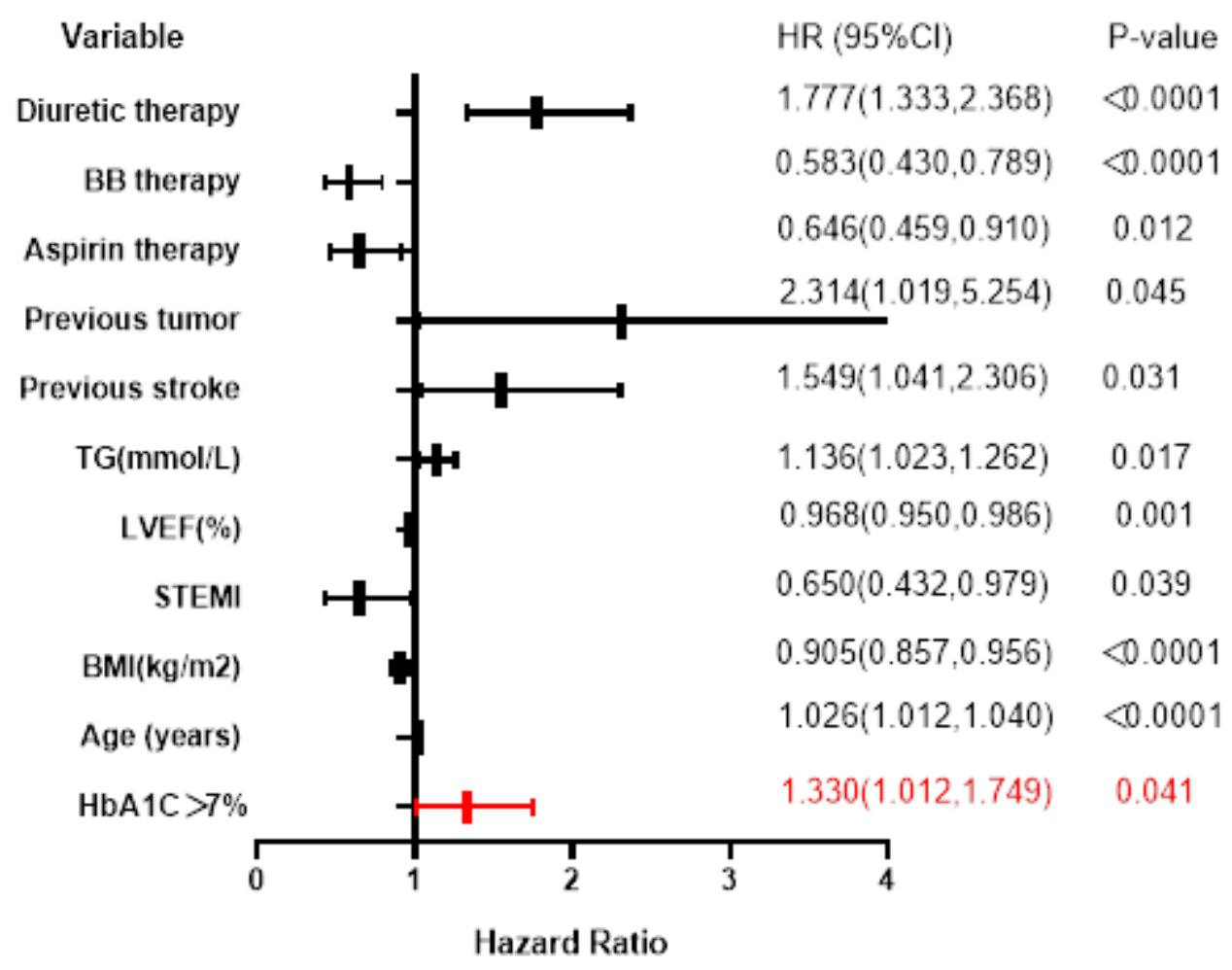

Figure 3

Adjusted multivariate Cox proportional-hazard model for all-cause mortality in the overall population. HR, hazard ratio; Cl: confidence interval; BB, beta blocker; TG, triglycerides; LVEF, left ventricular ejection fraction; STEMI, ST-segment elevation myocardial infarction; BMI, body mass index; HbA1c, hemoglobin A1c. 

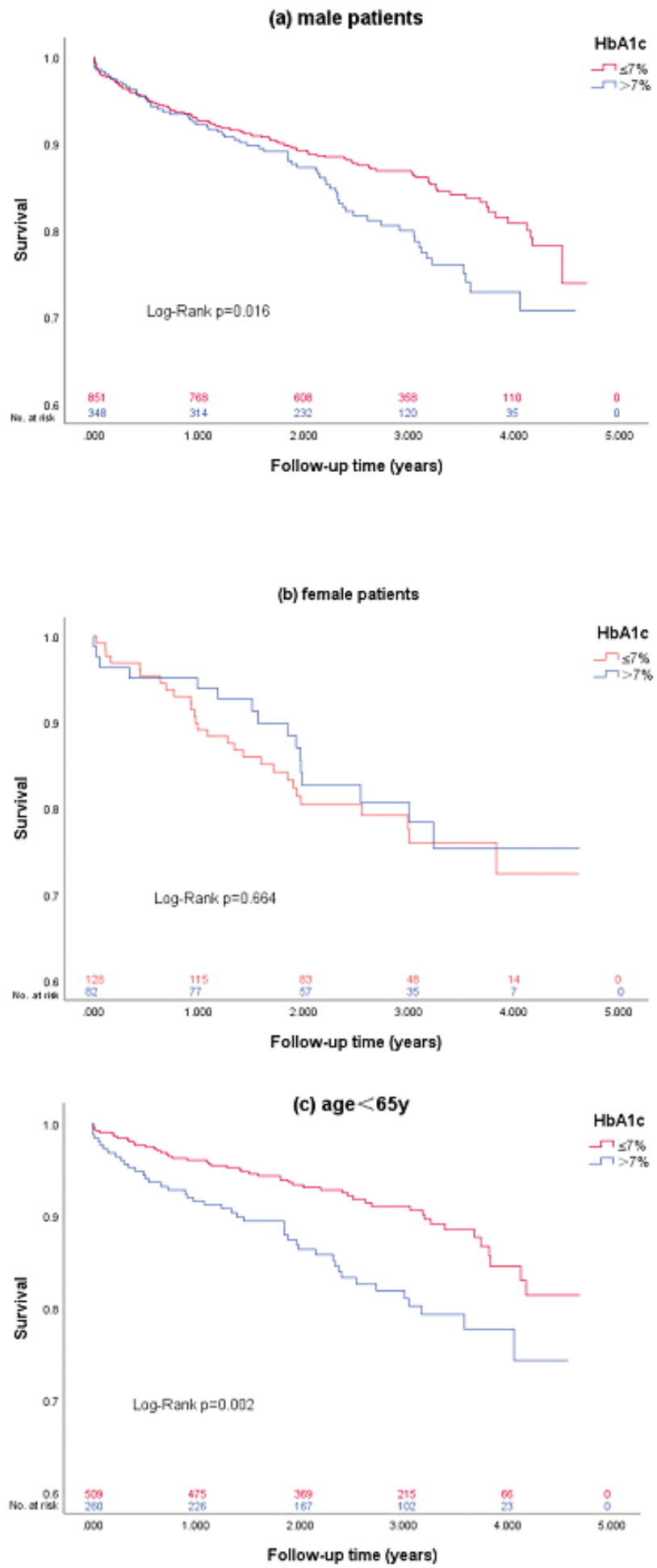

\section{Figure 4}

Kaplan-Meier survival curves of gender ( $a$ and $b$ ) and age (c) subgroup patients with $\mathrm{HbA} 1 \mathrm{c} \leq 7 \%$ versus $\mathrm{HbA} 1 \mathrm{c} \bigotimes 7 \%$. 
(a) multivariable Cox proportional

hazard analysis in male population

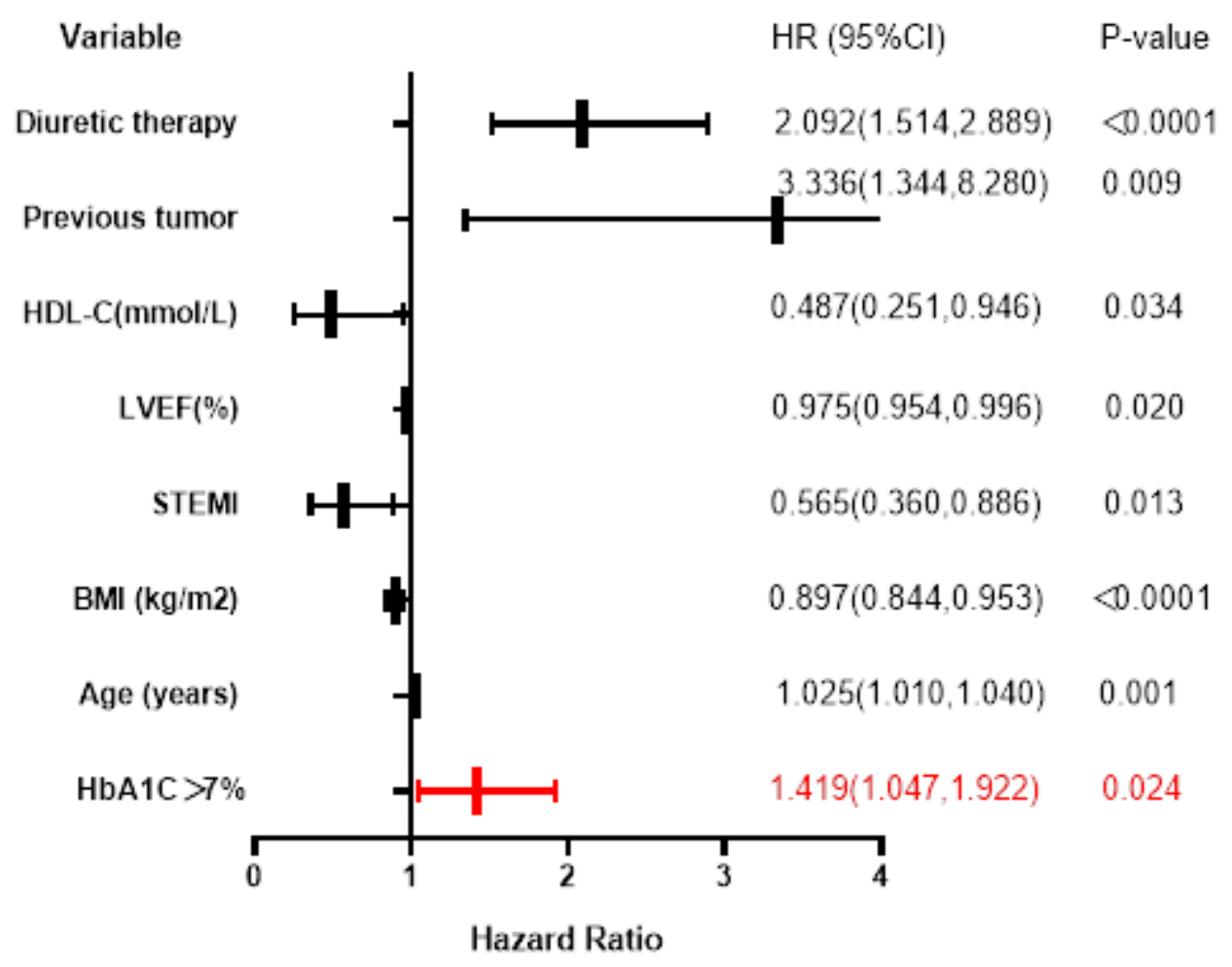

(b) multivariable Cox proportional hazard analysis in young population

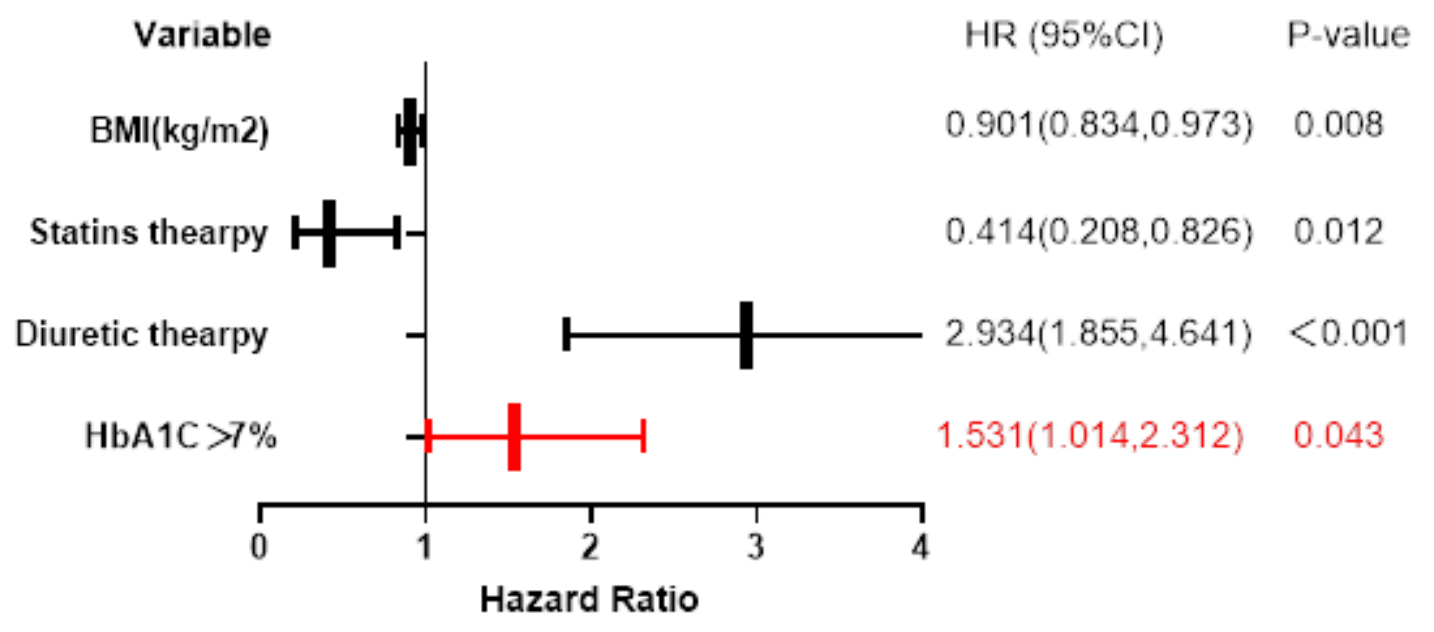

\section{Figure 5}

Adjusted multivariate Cox proportional-hazards model for all-cause mortality in the male population (a) and in the younger population (b). HR: hazard ratio; Cl: confidence interval; HDL-C, high density lipoprotein cholesterol; LVEF, left ventricular ejection fraction; STENI, ST-segment elevation myocardial infarction; BMI, body Mass Index; HbA1c, hemoglobin A1c

\section{Supplementary Files}


This is a list of supplementary files associated with this preprint. Click to download.

- SupplementaryFigure1.docx

- SupplementaryFigure2.docx

- SupplementaryTable1.docx

- graphicalabstract.pptx 